УдК 339.986

\author{
M.V. Rukinov
}

\section{THEORETICAL AND METHODOLOGICAL APPROACHES TOWARDS MODELLING OF THE STRUCTURE OF NATIONAL SE- CURITY}

The paper analyzes the place of the national economic security within the system of national security. It is demonstrated that the basic legal acts of Russian Federation in the field of national security have important methodological problems that hinder the implementation of an effective system of national security. Main types of national security are identified. A system of interactions between them is built. The structure of the national economic security is corrected. The concept of the value security as the ability of the national economy to produce and distribute a sufficient amount of added value is introduced. Recommendations for amendment of the legislation of Russian Federation in the field of national security are formulated.

Keywords: national security, national economic security, added value.
М.В. Рукинов ${ }^{1}$

ТЕОРЕТИКО-МЕТОДОЛОГИЧЕСКИЕ ПОДХОДЫ К МОДЕЛИРОВАНИЮ СТРУКТУРЫ НАЦИОНАЛЬНОЙ БЕЗОПАСНОСТИ

В статье рассмотрено место национальной экономической безопасности в системе национальной безопасности. Показано, что основополагающие нормативные документы Российской Федерации в области национальной безопасности обладают важными методологическими недостатками, которые препятствуют выстраиванию эффективной системы национальной безопасности. Идентифицированы основные виды национальной безопасности. Построена система взаимосвязей между ними. Уточнена структура национальной экономической безопасности. Введено понятие стоимостной безопасности как способности национальной экономики производить и распределять достаточный объём добавленной стоимости. Сформулированы рекомендации по совершенствованию нормативной базы нашей страны в области национальной безопасности.

Ключевые слова: национальная безопасность, национальная экономическая безопасность, добавленная стоимость.

DOI: 10.36807/2411-7269-2020-1-20-17-27

Национальная экономическая безопасность (НЭБ) представляет собой многоуровневое понятие, охватывающее разные аспекты хозяйственной жизни страны в отраслевом, региональном, организационном и иных аспектах, и тесно связанное с другими видами национальной безопасности (НБ). Однако в научной и прикладной литературе пока не было предложено единого подхода ни к составу НЭБ (т.е. к перечню тех подвидов безопасности, которые в комплексе формируют НЭБ), ни к структуре связей между этими подвидами, ни к системе взаимоотношений между НЭБ и другими элементами национальной безопасности (т.е. к месту НЭБ в системе национальной безопасности) [1]-[4]. Это создаёт проблемы как с точки зрения теоретического моделирования НЭБ, так и с точки зрения разработки эффрективной стратегии в области НЭБ. По этой причине мы считаем необходимым раскрыть эти аспекты и представить наш подход к моделированию НЭБ.

Начать наш анализ целесообразно с изучения отечественной нормативной базы в области НБ и НЭБ, поскольку именно она отражает видение руководства страны относительно состава национальной безопасности и национальной экономической безопасности как системы, регламентирует их виды с учётом стратегических интересов Российской Федерации и устанавливает инструменты их достижения [5].

В соответствии со "Стратегией национальной безопасности Российской Федерации" национальная безопасность нашей страны определяется как "состояние защищённости личности, общества и государства от внутренних и внешних угроз, при котором

\footnotetext{
1 Рукинов М.В., докторант, кандидат экономических наук; Ленинградский государственный университет им. А.С. Пушкина, г. Пушкин, Санкт-Петербург

Rukinov M.V., Doctoral student, PhD in Economics, Leningrad State University named after A.S. Pushkin, Pushkin, St. Petersburg

E-mail:a97440533@protonmail.com
} 
обеспечиваются реализация конституционных прав и свобод граждан Российской Федерации (далее - граждане), достойные качество и уровень их жизни, суверенитет, независимость, государственная и территориальная целостность, устойчивое социальноэкономическое развитие Российской Федерации. Национальная безопасность включает в себя оборону страны и все виды безопасности, предусмотренные Конституцией Российской Федерации и законодательством Российской Федерации, прежде всего государственную, общественную, информационную, экологическую, экономическую, транспортную, энергетическую безопасность, безопасность личности" [6]. Перечень блоков безопасности, включенных в "Стратегию национальной безопасности Российской Федерации" и соответствующих ключевым национальным стратегическим интересам, представлен в Табл. 1.

Таблица 1 - Анализ структуры "Стратегии национальной безопасности Российской Федерации"

\begin{tabular}{|c|c|c|}
\hline $\begin{array}{c}\text { Блок национальной } \\
\text { безопасности }\end{array}$ & Сущность & Комментарии \\
\hline 1 & 2 & 3 \\
\hline $\begin{array}{l}\text { Военная безопас- } \\
\text { ность }\end{array}$ & $\begin{array}{l}\text { "Состояние защищённости жизненно важных } \\
\text { интересов личности, общества и государства } \\
\text { от внешних и внутренних военных угроз, } \\
\text { связанных с применением военной силы или } \\
\text { угрозой её применения, характеризуемое } \\
\text { отсутствием военной угрозы либо способно- } \\
\text { стью ей противостоять" }\end{array}$ & $\begin{array}{l}\text { В "Стратегии национальной } \\
\text { безопасности Российской Фе- } \\
\text { дерации" определение военной } \\
\text { безопасности отсутствует, од- } \\
\text { нако даётся отсылка к "Военной } \\
\text { доктрине Российской Федера- } \\
\text { ции" [7] (откуда и взято приве- } \\
\text { дённое определение) }\end{array}$ \\
\hline $\begin{array}{l}\text { Государственная и } \\
\text { общественная без- } \\
\text { опасность }\end{array}$ & $\begin{array}{l}\text { "Защита конституционного строя, суверените- } \\
\text { та, государственной и территориальной це- } \\
\text { лостности Российской Федерации, основных } \\
\text { прав и свобод человека и гражданина, сохра- } \\
\text { нение гражданского мира, политической и со- } \\
\text { циальной стабильности в обществе, защита } \\
\text { населения и территорий от чрезвычайных } \\
\text { ситуаций природного и техногенного характе- } \\
\text { ра" }\end{array}$ & $\begin{array}{l}\text { - Отсутствует разграничение } \\
\text { государственной и обществен- } \\
\text { ной безопасности. } \\
\text { - Дан перечень целей данных } \\
\text { видов национальной безопас- } \\
\text { ности (без их разграничения), } \\
\text { однако определение отсутству- } \\
\text { ет }\end{array}$ \\
\hline $\begin{array}{l}\text { Национальная без- } \\
\text { опасность в области } \\
\text { качества жизни }\end{array}$ & $\begin{array}{l}\text { "Развитие человеческого потенциала, удовле- } \\
\text { творение материальных, социальных и духов- } \\
\text { ных потребностей граждан, снижение уровня } \\
\text { социального и имущественного неравенства } \\
\text { населения, прежде всего, за счёт роста его } \\
\text { доходов" }\end{array}$ & $\begin{array}{l}\text { - Включает в себя в качестве } \\
\text { одного из элементов продо- } \\
\text { вольственную безопасность (п. } \\
54 \text { "Стратегии национальной } \\
\text { безопасности Российской Фе- } \\
\text { дерации"). Определения продо- } \\
\text { вольственной безопасности нет. } \\
\text { - Нет перечня остальных видов } \\
\text { национальной безопасности } \\
\text { (кроме продовольственной), } \\
\text { которые могут относиться к } \\
\text { этому блоку }\end{array}$ \\
\hline $\begin{array}{l}\text { Национальная без- } \\
\text { опасность в области } \\
\text { экономического роста }\end{array}$ & $\begin{array}{l}\text { "Развитие экономики страны, обеспечение } \\
\text { экономической безопасности и создание } \\
\text { условий для развития личности, перехода } \\
\text { экономики на новый уровень технологическо- } \\
\text { го развития, вхождения России в число } \\
\text { стран-лидеров по объёму валового внутрен- } \\
\text { него продукта и успешного противостояния } \\
\text { влиянию внутренних и внешних угроз" }\end{array}$ & $\begin{array}{l}\text { - Включает в себя в качестве } \\
\text { одного из элементов экономи- } \\
\text { ческую безопасность (п. } 55 \\
\text { "Стратегии национальной без- } \\
\text { опасности Российской Федера- } \\
\text { ции"). Определения экономиче- } \\
\text { ской безопасности нет. } \\
\text { - Нет перечня остальных видов } \\
\text { национальной безопасности } \\
\text { (кроме экономической), которые } \\
\text { могут относиться к этому блоку }\end{array}$ \\
\hline $\begin{array}{l}\text { Национальная без- } \\
\text { опасность в области } \\
\text { науки, технологий и } \\
\text { образования }\end{array}$ & $\begin{array}{l}\text { "Развитие системы научных, проектных и } \\
\text { научно-технологических организаций, способ- } \\
\text { ной обеспечить модернизацию национальной } \\
\text { экономики, реализацию конкурентных пре- } \\
\text { имуществ Российской Федерации, оборону } \\
\text { страны, государственную и общественную } \\
\text { безопасность, а также формирование научно- } \\
\text { технических заделов на перспективу; } \\
\text { повышение социальной мобильности, качества } \\
\text { общего, профессионального и высшего обра- } \\
\text { зования, его доступности для всех категорий } \\
\text { граждан, а также развитие фундаментальных } \\
\text { научных исследований" }\end{array}$ & $\begin{array}{l}\text { - Дан перечень целей данного } \\
\text { вида национальной безопасно- } \\
\text { сти, однако определение отсут- } \\
\text { ствует. } \\
\text { - Включает в себя в качестве } \\
\text { одного из элементов технологи- } \\
\text { ческую безопасность (п. } 69 \\
\text { "Стратегии национальной без- } \\
\text { опасности Российской Федера- } \\
\text { ции"). Определения технологи- } \\
\text { ческой безопасности нет. } \\
\text { - Нет перечня остальных видов } \\
\text { национальной безопасности } \\
\text { (кроме технологической), кото- } \\
\text { рые могут относиться к этому } \\
\text { блоку }\end{array}$ \\
\hline
\end{tabular}


Продолжение таблицы 1

\begin{tabular}{|c|c|c|}
\hline 1 & 2 & 3 \\
\hline Здравоохранение & $\begin{array}{l}\text { "Увеличение продолжительности жизни, сни- } \\
\text { жение уровня инвалидности и смертности } \\
\text { населения, увеличение численности населе- } \\
\text { ния; } \\
\text { повышение доступности и качества медицин- } \\
\text { ской помощи; } \\
\text { совершенствование вертикальной системы } \\
\text { контроля качества, эффективности и безопас- } \\
\text { ности лекарственных средств; } \\
\text { соблюдение прав граждан в сфере охраны } \\
\text { здоровья и обеспечение связанных с этими } \\
\text { правами государственных гарантий" }\end{array}$ & $\begin{array}{l}\text { Дан перечень целей данного } \\
\text { вида национальной безопасно- } \\
\text { сти, однако определение отсут- } \\
\text { ствует }\end{array}$ \\
\hline $\begin{array}{l}\text { Национальная без- } \\
\text { опасность в области } \\
\text { культуры }\end{array}$ & $\begin{array}{l}\text { "Сохранение и приумножение традиционных } \\
\text { российских духовно-нравственных ценностей } \\
\text { как основы российского общества, воспитание } \\
\text { детей и молодёжи в духе гражданственности; } \\
\text { сохранение и развитие общероссийской иден- } \\
\text { тичности народов Российской Федерации, } \\
\text { единого культурного пространства страны; } \\
\text { повышение роли России в мировом гумани- } \\
\text { тарном и культурном пространстве" }\end{array}$ & $\begin{array}{l}\text { Дан перечень целей данного } \\
\text { вида национальной безопасно- } \\
\text { сти, однако определение отсут- } \\
\text { ствует }\end{array}$ \\
\hline $\begin{array}{l}\text { Экологическая без- } \\
\text { опасность и рацио- } \\
\text { нальное природо- } \\
\text { пользование }\end{array}$ & $\begin{array}{l}\text { "Сохранение и восстановление природных } \\
\text { систем, обеспечение качества окружающей } \\
\text { среды, необходимого для жизни человека и } \\
\text { устойчивого развития экономики; } \\
\text { ликвидация экологического ущерба от хозяй- } \\
\text { ственной деятельности в условиях возраста- } \\
\text { ющей экономической активности и глобальных } \\
\text { изменений климата" }\end{array}$ & $\begin{array}{l}\text { Дан перечень целей данного } \\
\text { вида национальной безопасно- } \\
\text { сти, однако определение отсут- } \\
\text { ствует }\end{array}$ \\
\hline $\begin{array}{l}\text { Стратегическая ста- } \\
\text { бильность и равно- } \\
\text { правное стратегиче- } \\
\text { ское партнёрство }\end{array}$ & $\begin{array}{l}\text { "Создание стабильной и устойчивой системы } \\
\text { международных отношений, опирающейся на } \\
\text { международное право и основанной на прин- } \\
\text { ципах равноправия, взаимного уважения, не- } \\
\text { вмешательства во внутренние дела госу- } \\
\text { дарств, взаимовыгодного сотрудничества, } \\
\text { политического урегулирования глобальных и } \\
\text { региональных кризисных ситуаций" }\end{array}$ & $\begin{array}{l}\text { Дан перечень целей данного } \\
\text { вида национальной безопасно- } \\
\text { сти, однако определение отсут- } \\
\text { ствует }\end{array}$ \\
\hline
\end{tabular}

Табл. 1 позволяет выявить следующие общие содержательные проблемы, присущие "Стратегии национальной безопасности Российской Федерации" как основополагающему документу в области национальной безопасности нашей страны:

1. Структура разделов "Стратегии национальной безопасности Российской Федерации" (т.е. законодательно выделяемых блоков национальной безопасности) ни по составу, ни по содержанию не соответствует перечню видов национальной безопасности, перечисленных в начале этого документа (где говорится о таких видах безопасности, как государственная, общественная, информационная, экологическая, экономическая, транспортная, энергетическая безопасность, безопасность личности [6]). Иными словами, блоки национальной безопасности, регламентируемые "Стратегией национальной безопасности Российской Федерации" и соответствующие установленным ей национальным стратегическим интересам, не соответствуют видам НБ, выделяемым в этом документе, а состав этих блоков (т.е. соответствие между разделами документа и разными видами НБ) нигде не описывается. Методологически это некорректно, поскольку в начале документа вводятся виды национальной безопасности, но структура документа строится на основе не этих видов, а на основе неких блоков национальной безопасности, состав и структура которых с точки зрения связанных с ними видов НБ неясны. В частности, среди разделов "Стратегии национальной безопасности Российской Федерации" отсутствует раздел, посвящённый национальной экономической безопасности - вместо него есть раздел о национальной безопасности в области экономического роста, что, очевидно, не равнозначно НЭБ. Напротив, есть раздел, посвящённый национальной безопасности в области культуры, однако напрямую он не соответствует ни одному из видов национальной безопасности, указанных в начале документа. Среди разделов нет ни одного, который бы напрямую соответствовал такому виду безопасности, как безопасность личности - этот вид безопасности, насколько можно судить, размыт между несколькими разделами (государственная и общественная безопасность, национальная безопасность в области качества жизни, здравоохранение). Из-за этого сложно определить, при помощи каких инструментов предполагается реализовывать различные виды национальной безопасности. 
Отметим, что у структурирования "Стратегии национальной безопасности Российской Федерации" не по видам НБ, а по блокам (т.е. по стратегическим национальным интересам) есть своя логика, поскольку задача НБ - создавать условия для устойчивого достижения национальных интересов. Однако, тем не менее, несмотря на тесную связь между НБ и стратегическими национальными интересами, эти понятия не равнозначны. В результате из-за такого структурирования данный документ представляет собой не столько стратегию национальной безопасности, сколько стратегию достижения стратегических национальных интересов, тогда как собственно НБ осталась в нём на втором плане.

2. Перечень элементов НБ, рассмотренных в тексте "Стратегии национальной безопасности Российской Федерации", не соответствует структуре выделяемых в начале этого документа видов национальной безопасности. В частности, государственная и общественная безопасность рассматриваются совместно. Энергетическая безопасность, указанная в начале документа в качестве самостоятельного вида национальной безопасности, в тексте документа входит в состав национальной безопасности в области экономического роста (но при этом ничего не говорится о том, какие ещё виды НБ относятся к этому блоку), т.е. может рассматриваться (с определёнными оговорками) как компонент экономической безопасности. В составе национальной безопасности в области качества жизни выделяется продовольственная безопасность - однако в начале документа этот вид национальной безопасности никак не упоминается. Это затрудняет выявление соотношений между разными видами национальной безопасности.

3. Перечень выделенных в начале документа видов национальной безопасности неполон. Помимо уже приведённого выше примера с продовольственной безопасностью такова ситуация с международной безопасностью, которая вскользь упоминается в тексте "Стратегии национальной безопасности Российской Федерации", однако в начале его не выделяется в качестве самостоятельного элемента НБ.

4. Практически для всех блоков и видов национальной безопасности, приведённых в "Стратегии национальной безопасности Российской Федерации", определения отсутствуют - даны только цели, на которые направлен соответствующий вид НБ. Это затрудняет понимание сущности различных видов (и блоков) НБ. Только в одном случае (военная безопасность) даётся отсылка к другому документу, в котором приводится определение данного вида НБ. Из-за этого "Стратегия национальной безопасности Российской Федерации" плохо справляется со своими функциями информационной основы системы НБ нашей страны. Логично было бы, чтобы для тех видов НБ, для которых уже существуют нормативные определения, давались бы отсылки к тем нормативно-правовым актам, в которых сформулированы эти определения (такова ситуация с продовольственной безопасностью), а для тех видов НБ, которые не регламентируются собственной нормативно-правовой базой, "Стратегия национальной безопасности Российской Федерации" приводила бы такие определения.

5. В тексте "Стратегии национальной безопасности Российской Федерации" присутствуют терминологические противоречия и несоответствия. В частности, в п. 56 говорится о национальной безопасности в области экономики, а в п. 57 - о национальной экономической безопасности, но неясно, являются ли эти термины синонимами.

6. Не всегда ясна логика законодателя при отнесении того или иного вида НБ к разным блокам или же к другим видам НБ. Например, достаточно спорным представляется включение продовольственной безопасности в блок "Национальная безопасность в области качества жизни".

Сказанное выше означает, что, несмотря на важность "Стратегии национальной безопасности Российской Федерации" как методологической и информационной основы системы НБ России, она обладает серьёзными недостатками и, в частности, не позволяет выяснить соотношение между разными видами НБ (отметим, что на низкий методологический уровень этого документа указывали ранее и другие специалисты [5], что является подтверждением обоснованности авторских выводов).

Выявить место и роль НЭБ в системе НБ на основе "Стратегии национальной безопасности Российской Федерации" затруднительно. Экономическая безопасность входит в состав блока "Экономический рост", однако её место в этом блоке, а также связь с другими блоками неясны. Определение национальной экономической безопасности отсутствует. Однако в п. 58 описывается, каким образом реализуется национальная экономическая безопасность ("Обеспечение экономической безопасности осуществляется путём развития промышленно-технологической базы и национальной инновационной системы, модернизации и развития приоритетных секторов национальной экономики, повышения инвестиционной привлекательности Российской Федерации, улучшения делово- 
го климата и создания благоприятной деловой среды" [1]). Кроме того, в п. 60 даётся описание энергетической безопасности ("включает в себя устойчивое обеспечение внутреннего спроса на энергоносители стандартного качества, рост энергоэффективности и энергосбережения, конкурентоспособности отечественных энергетических компаний и производителей энергоресурсов, предотвращение десицита топливно-энергетических ресурсов, создание стратегических запасов топлива, резервных мощностей, производство комплектующего оборудования, стабильное функционирование систем энерго- и теплоснабжения" [6]).

Тем не менее, "Стратегия национальной безопасности Российской Федерации" в неявной форме содержит важное указание на то, что в обеспечении одного и того же блока безопасности (т.е. национального стратегического интереса) участвуют разные виды национальной безопасности. Это позволяет говорить о тесной взаимосвязи и взаимозависимости разных видов НБ. Ещё одним важным выводом из анализа этого документа можно считать то, что в нём (также неявно) фрактически выделяются как минимум три уровня национальной безопасности: национальная безопасность в целом (её можно назвать интегральной национальной безопасностью), виды национальной безопасности (ключевые компоненты НБ; например, экономическая безопасность) и подвиды НБ (входят в состав видов НБ и обеспечивают их реализацию; примером может быть энергетическая безопасность как элемент экономической безопасности).

Определение НЭБ даётся в "Стратегии национальной экономической безопасности Российской Федерации на период до 2030 года" ("состояние защищённости национальной экономики от внешних и внутренних угроз, при котором обеспечиваются экономический суверенитет страны, единство её экономического пространства, условия для реализации стратегических национальных приоритетов Российской Федерации" [8]). Однако связь НЭБ с другими видами НБ, её место в системе НБ и структура НЭБ с точки зрения входящих в неё подвидов НБ не раскрываются.

Таким образом, нам необходимо установить перечень ключевых видов НБ и показать, как они связаны друг с другом.

Прежде чем перейти к решению этой задачи, рассмотрим взгляды ведущих специалистов на структуру НЭБ. В основополагающей работе по проблемам экономической безопасности под редакцией В.К. Сенчагова указывается, что в составе НЭБ можно выделить финансовую, энергетическую, военную (оборонную), оборонно-промышленную и продовольственную безопасность [9]. Ниже, в Табл. 2, приведены определения этих видов безопасности по В.К. Сенчагову [9].

Таблица 2 - Элементы национальной экономической безопасности

\begin{tabular}{|l|l|}
\hline \multicolumn{1}{|c|}{ Вид безопасности } & \multicolumn{1}{|c|}{ Определение } \\
\hline $\begin{array}{l}\text { Финансовая без- } \\
\text { опасность [9. С. 73] }\end{array}$ & $\begin{array}{l}\text { Состояние финансово-банковской системы, при котором гос- } \\
\text { ударство может в определённых пределах гарантировать об- } \\
\text { щеэкономические условия функционирования государствен- } \\
\text { ных учреждений власти и рыночных институтов }\end{array}$ \\
\hline $\begin{array}{l}\text { Оборонная безопас- } \\
\text { ность [9. С. 74] }\end{array}$ & $\begin{array}{l}\text { Состояние структуры армии, её готовность к отражению } \\
\text { внешних угроз }\end{array}$ \\
\hline $\begin{array}{l}\text { Оборонно- } \\
\text { промышленная без- } \\
\text { опасность [9. С. 74] }\end{array}$ & $\begin{array}{l}\text { Состояние военно-промышленного комплекса, его способ- } \\
\text { ность к поддержанию военной (оборонной) безопасности при } \\
\text { самом неблагоприятном развитии международной ситуации и и } \\
\text { угрозах понижения геополитического статуса России }\end{array}$ \\
\hline $\begin{array}{l}\text { Продовольственная } \\
\text { безопасность [9. С. }\end{array}$ & $\begin{array}{l}\text { Обеспечение устойчивого (преимущественно внутреннего) } \\
\text { производства основных продуктов питания и их доступность } \\
\text { населению с учётом медицинских норм, защита населения от } \\
\text { недоброкачественного продовольствия, защита внутреннего } \\
\text { рынка от избыточных, демпинговых поставок сельскохозяй- } \\
\text { ственной продукции, создание резервов, страховых запасов и } \\
\text { условий для выхода на внешний рынок национальных сель- } \\
\text { хозпроизводителей }\end{array}$ \\
\hline
\end{tabular}

Интересно подчеркнуть, что В.К. Сенчагов, выделяя энергетическую безопасность в качестве одного из ключевых элементов НЭБ, не даёт определения энергетической безопасности (именно поэтому оно отсутствует в Табл. 2). Он лишь указывает на важность энергетики для эффективного функционирования национальной экономики [9. С. 
73-74]. При этом в качестве самостоятельного элемента НЭБ далее в этой работе выделяется транспортная безопасность [9. С. 252] (определение которой тоже отсутствует).

Кроме того, в соответствии с подходом В.К. Сенчагова, военная (оборонная) безопасность относится к НЭБ, а не является самостоятельным элементом национальной безопасности. Напротив, другие исследователи предпочитают включать оборонную безопасность в состав национальной безопасности - наравне с НЭБ [10] (т.е. выделяют её в качестве равноправного вида НБ). Как было показано выше, равный НЭБ статус военная (оборонная) безопасность имеет и в "Стратегии национальной безопасности Российской Федерации".

Интересно сравнить мнение В.К. Сенчагова и его соавторов со "Стратегией национальной безопасности Российской Федерации" ещё по одному пункту. В соответствии со "Стратегией", продовольственная безопасность относится к блоку "Повышение качества жизни населения", тогда как В.К. Сенчагов включает её в НЭБ.

Таким образом, в научных публикациях по проблеме НЭБ есть противоречия, которые препятствуют пониманию структуры НЭБ и её места в системе НБ. Но при этом очевидно, что НЭБ связана с другими видами НБ. Это, в частности, подтверждается тем, что военная и продовольственная безопасность могут включаться в состав НЭБ или же выделяться из неё - либо в качестве самостоятельных видов НБ (военная безопасность), либо как подвиды безопасности, входящие в состав других видов НБ (как продовольственная безопасность). Объяснить возможность придания одному и тому же виду НБ разного статуса можно только одним образом: что разные виды НБ тесно связаны друг с другом и влияют друг на друга. За счёт этого, в частности, в НЭБ можно найти элементы других видов НБ (как это имеет место в случае с военной безопасностью; специалисты указывают на наличие в НЭБ неэкономической составляющей [11]), и, напротив, в других видах НБ можно найти экономический компонент.

Это означает, что строго определить место НЭБ в системе НБ страны невозможно из-за наличия этих взаимосвязей и взаимного влияния. И поэтому, вместо однозначного противопоставления НЭБ другим видам НБ необходимо, напротив, сосредоточиться на анализе их взаимного влияния. По этой причине следует, как сказано выше, выявить виды НБ (т.е. самостоятельные элементы НБ).

К числу таких видов НБ, по нашему мнению, относятся:

1. Национальная экономическая безопасность (НЭБ).

2. Национальная военная безопасность (НВБ).

3. Национальная государственная безопасность - стабильность конституционного строя, сохранение национального суверенитета и территориальной целостности (НГБ).

4. Национальная общественная безопасность - обеспечение прав и свобод граждан, противодействие преступности, защита от природных и техногенных катастрофр (НОБ).

5. Национальная экологическая безопасность (НЭкБ) [11]-[13].

6. Национальная безопасность личности - создание условий для самореализации каждого человека и социальных групп, защита его от деструктивных социальных процессов, повышение качества жизни, обеспечение здоровья граждан (НБЛ).

7. Национальная культурная безопасность (НКБ), предполагающая создание условий для сохранения и развития самобытной культуры России и всех населяющих её народов, содействие в адаптации к этой культуре лиц, приезжающих в Россию для постоянного проживания, повышения статуса русского языка в мире, развитие образования как инструмента сохранения, развития и укрепления культуры, обеспечение условий для функционирования культуры нашей страны как инструмента мягкой силы.

8. Национальная научно-технологическая безопасность (ННТБ), которая формирует условия для обеспечения устойчивого научного и технологического развития России.

9. Национальная стратегическая безопасность (НСБ), направленная на выстраивание наиболее выгодных для России отношений с другими государствами и наднациональными (и вненациональными) образованиями.

Взаимосвязь между этими видами национальной безопасности удобнее всего представить в виде балансовой таблицы (Табл. 3).

Табл. 3 показывает, что каждый вид НБ, с одной стороны, опирается на все остальные виды НБ, а с другой стороны - сам способствует их достижению. Например, безопасность личности опирается на культурную безопасность в связи с тем, что именно в рамках культуры формируется самосохранительное и здоровьесберегающее поведение [14]. 
Таблица 3 - Взаимосвязь видов национальной безопасности

\begin{tabular}{|c|c|c|c|c|c|c|c|c|c|}
\hline & НЭБ & HBE & НГБ & HOБ & НЭкБ & НБЛ & НКБ & HHTБ & $\mathrm{HCБ}$ \\
\hline НЭБ & & $\begin{array}{l}\text { HBБ } \\
\text { HЭБ }\end{array}$ & $\begin{array}{l}\text { НГБ } \\
\text { НЭБ }\end{array}$ & $\begin{array}{l}\text { НОБ } \\
\text { НЭБ }\end{array}$ & $\begin{array}{l}\text { НЭкБ / } \\
\text { НЭБ }\end{array}$ & $\begin{array}{l}\text { НБЛ } \\
\text { НЭБ }\end{array}$ & $\begin{array}{l}\text { НКБ } \\
\text { НЭБ }\end{array}$ & $\begin{array}{l}\text { НHТБ } \\
\text { НЭБ }\end{array}$ & $\begin{array}{l}\text { НСБ / } \\
\text { НЭБ }\end{array}$ \\
\hline $\mathrm{HBO}$ & $\begin{array}{l}\text { HЭБ } \\
\text { HBБ }\end{array}$ & & $\begin{array}{l}\text { НГБ } \\
\text { НВБ }\end{array}$ & $\begin{array}{l}\text { HOB } \\
\text { HBE }\end{array}$ & $\begin{array}{l}\text { НЭкБ / } \\
\text { НВБ }\end{array}$ & $\begin{array}{l}\text { HБЛ } \\
\text { HВБ }\end{array}$ & $\begin{array}{l}\text { HKE } \\
\text { HBE }\end{array}$ & $\begin{array}{l}\text { HHTБ } \\
\text { HBE }\end{array}$ & $\begin{array}{ll}\text { HCE } & \text { HBS }\end{array}$ \\
\hline НГБ & $\begin{array}{l}\text { НЭБ } \\
\text { НГБ }\end{array}$ & $\begin{array}{l}\text { HBБ } \\
\text { HГБ }\end{array}$ & & $\begin{array}{l}\text { НОБ } \\
\text { НГБ }\end{array}$ & $\begin{array}{l}\text { НЭкБ / } \\
\text { НГБ }\end{array}$ & $\begin{array}{l}\text { НБЛ } \\
\text { НГБ }\end{array}$ & $\begin{array}{l}\text { НКБ } \\
\text { НГБ }\end{array}$ & $\begin{array}{l}\text { ННТБ } \\
\text { НГБ }\end{array}$ & $\begin{array}{l}\text { НСБ / } \\
\text { НГБ }\end{array}$ \\
\hline НОБ & $\begin{array}{ll}\text { НЭБ } & / \\
\text { НОБ } & \\
\end{array}$ & $\begin{array}{ll}\text { HBE } & / \\
\text { HOS }\end{array}$ & $\begin{array}{l}\text { НГБ } \\
\text { НОБ }\end{array}$ & & $\begin{array}{l}\text { НЭкБ / } \\
\text { НОБ }\end{array}$ & $\begin{array}{l}\text { НБЛ } \\
\text { НОБ }\end{array}$ & $\begin{array}{l}\text { HKБ } \\
\text { HOБ }\end{array}$ & $\begin{array}{l}\text { HHTБ } \\
\text { HOS }\end{array}$ & $\begin{array}{l}\text { HCБ } \\
\text { HOБ }\end{array}$ \\
\hline НЭкБ & $\begin{array}{ll}\text { НЭБ / } \\
\text { НЭкБ }\end{array}$ & $\begin{array}{ll}\text { НВБ } & / \\
\text { НЭкБ }\end{array}$ & $\begin{array}{l}\text { НГБ } \\
\text { НЭкБ }\end{array}$ & $\begin{array}{l}\text { НОБ } \\
\text { НЭкБ }\end{array}$ & & $\begin{array}{ll}\text { НБЛ / } \\
\text { НЭкБ }\end{array}$ & $\begin{array}{l}\text { НКБ } \\
\text { НЭкБ }\end{array}$ & $\begin{array}{l}\text { ННТБ } \\
\text { НЭкБ }\end{array}$ & $\begin{array}{l}\text { НСБ / } \\
\text { НЭкБ }\end{array}$ \\
\hline НБЛ & $\begin{array}{l}\text { НЭБ } \\
\text { НБЛ }\end{array}$ & $\begin{array}{l}\text { HBБ } \\
\text { HБЛ }\end{array}$ & $\begin{array}{l}\text { НГБ } \\
\text { НБЛ }\end{array}$ & $\begin{array}{l}\text { НОБ } \\
\text { НБЛ }\end{array}$ & $\begin{array}{l}\text { НЭкБ } \\
\text { НБЛ }\end{array}$ & & $\begin{array}{l}\text { НКБ } \\
\text { НБЛ }\end{array}$ & $\begin{array}{l}\text { ННТБ } \\
\text { НБЛ }\end{array}$ & $\begin{array}{l}\text { НСБ } \\
\text { НБЛ }\end{array}$ \\
\hline НКБ & $\begin{array}{l}\text { НЭБ } \\
\text { НКБ }\end{array}$ & $\begin{array}{l}\text { HBE } \\
\text { HКБ }\end{array}$ & $\begin{array}{l}\text { НГБ } \\
\text { НКБ }\end{array}$ & $\begin{array}{l}\text { HOБ } \\
\text { HKБ }\end{array}$ & $\begin{array}{l}\text { НЭКБ } \\
\text { НКБ }\end{array}$ & $\begin{array}{l}\text { НБЛ } \\
\text { НКБ }\end{array}$ & & $\begin{array}{l}\text { HHTБ } \\
\text { HKБ }\end{array}$ & $\begin{array}{l}\text { НСБ } / \\
\text { НКБ }\end{array}$ \\
\hline НHТБ & $\begin{array}{ll}\text { НЭБ } & / \\
\text { ННТБ }\end{array}$ & $\begin{array}{ll}\text { HBБ } & / \\
\text { HНTБ }\end{array}$ & $\begin{array}{l}\text { НГБ } \\
\text { ННТБ }\end{array}$ & $\begin{array}{l}\text { НОБ } \\
\text { НHTБ }\end{array}$ & $\begin{array}{l}\text { НЭкБ / } \\
\text { ННТБ }\end{array}$ & $\begin{array}{ll}\text { НБЛ / } \\
\text { ННТБ }\end{array}$ & $\begin{array}{l}\text { НКБ } \\
\text { ННТБ }\end{array}$ & & $\begin{array}{l}\text { НСБ / } \\
\text { ННТБ }\end{array}$ \\
\hline НСБ & $\begin{array}{l}\text { НЭБ } \\
\text { НСБ }\end{array}$ & $\begin{array}{l}\text { HBБ } \\
\text { HCБ }\end{array}$ & $\begin{array}{l}\text { НГБ } \\
\text { НСБ } \\
\end{array}$ & $\begin{array}{l}\text { HOS } \\
\text { HCE }\end{array}$ & $\begin{array}{l}\text { НЭкБ } \\
\text { НСБ }\end{array}$ & $\begin{array}{l}\text { НБЛ } \\
\text { НСБ }\end{array}$ & $\begin{array}{l}\text { HKБ } \\
\text { HCБ }\end{array}$ & $\begin{array}{l}\text { HHTE } \\
\text { HCE }\end{array}$ & \\
\hline
\end{tabular}

Раскрыть всю систему этого взаимного влияния не представляется возможным, однако мы попытаемся показать систему взаимосвязей НЭБ и других видов национальной безопасности. Под прямым влиянием мы понимаем влияние НЭБ на соответствующий вид НБ, а под обратным влиянием - влияние этого вида НБ на НЭБ. В Табл. 4 прямое влияние представлено элементами, расположенными под главной диагональю матрицы, а обратное влияние - элементами, расположенными над главной диагональю.

Таблица 4 - Анализ взаимного влияния различных видов национальной безопасности

\begin{tabular}{|c|c|c|}
\hline Вид НБ & Прямое влияние & Обратное влияние \\
\hline 1 & 2 & 3 \\
\hline HBE & $\begin{array}{l}\text { - Создание производственной базы для } \\
\text { военной организации государства. } \\
\text { - Источник ресурсного обеспечения для } \\
\text { военной организации государства }\end{array}$ & $\begin{array}{l}\text { - Силовая защита экономического потенциала } \\
\text { страны. } \\
\text { - Устойчивый спрос на продукцию и услуги (вклю- } \\
\text { чая научно-исследовательские и образователь- } \\
\text { ные) в интересах военной организации государ- } \\
\text { ства }\end{array}$ \\
\hline НГБ & $\begin{array}{l}\text { - Создание экономической базы для струк- } \\
\text { тур, противодействующих угрозам госу- } \\
\text { дарственной безопасности. } \\
\text { - Создание экономической базы для недо- } \\
\text { пущения социальных потрясений (в том } \\
\text { числе через систему перераспределения } \\
\text { доходов) }\end{array}$ & $\begin{array}{l}\text { - Защита экономического потенциала страны. } \\
\text { - Обеспечение доступа к внешним ресурсам за- } \\
\text { крытого характера (промышленный шпионаж). } \\
\text { - Устойчивый спрос на продукцию и услуги (вклю- } \\
\text { чая научно-исследовательские и образователь- } \\
\text { ные) в интересах силовых структур и специаль- } \\
\text { ных служб государства }\end{array}$ \\
\hline HOБ & $\begin{array}{l}\text { - Создание экономической базы для реа- } \\
\text { лизации прав и свобод граждан. } \\
\text { - Создание экономической базы для обес- } \\
\text { печения деятельности структур, противо- } \\
\text { действующих угрозам для общества }\end{array}$ & $\begin{array}{l}\text { Создание условий максимального благоприят- } \\
\text { ствования для добросовестных экономических } \\
\text { агентов }\end{array}$ \\
\hline НЭкБ & $\begin{array}{l}\text { - Создание экономической базы для про- } \\
\text { ведения природоохранных мероприятий. } \\
\text { - Разработка и промышленное освоение } \\
\text { технологий, направленных на сбережение } \\
\text { окружающей среды }\end{array}$ & $\begin{array}{l}\text { Устойчивый спрос на продукты и услуги, связан- } \\
\text { ные с защитой окружающей среды }\end{array}$ \\
\hline НБЛ & $\begin{array}{l}\text { - Создание экономической базы для по- } \\
\text { вышения качества жизни и улучшения } \\
\text { здравоохранения. } \\
\text { - Создание качественных рабочих мест. } \\
\text { - Повышение производительности труда в } \\
\text { целях высвобождения времени человека. } \\
\text { - Развитие положительных форм гибкой } \\
\text { занятости [15] в целях достижения опти- } \\
\text { мального баланса между работой и лич- } \\
\text { ной жизнью. } \\
\text { - Расширение использования средств ав- } \\
\text { томатизации для высвобождения человека } \\
\text { от рутинного, изнурительного труда. } \\
\text { - Развитие нишевых бизнесов, направлен- } \\
\text { ных на удовлетворение специфических } \\
\text { потребностей отдельных категорий насе- } \\
\text { ления. } \\
\text { - Создание экономической базы для обес- } \\
\text { печения деятельности структур, противо- } \\
\text { действующих угрозам личности }\end{array}$ & $\begin{array}{l}\text { - Устойчивый спрос на товары и услуги, направ- } \\
\text { ленные на повышение качества жизни человека. } \\
\text { - Запрос на инновационные технологические и } \\
\text { организационные разработки, призванные повы- } \\
\text { сить качество жизни человека }\end{array}$ \\
\hline
\end{tabular}


Продолжение таблицы 4

\begin{tabular}{|c|c|c|}
\hline 1 & 2 & 3 \\
\hline НКБ & $\begin{array}{l}\text { - Создание устойчивого спроса на куль- } \\
\text { турные и образовательные услуги в инте- } \\
\text { ресах национальной экономики. } \\
\text { - Создание ресурсной базы для поддержки } \\
\text { и продвижения культуры }\end{array}$ & $\begin{array}{l}\text { Формирование и сохранение единой системы } \\
\text { трудовой и деловой этики, обеспечивающей вы- } \\
\text { сокий уровень эффективности функционирования } \\
\text { национальной экономики благодаря взаимному } \\
\text { доверию и высокой культуре труда }\end{array}$ \\
\hline НHTБ & $\begin{array}{l}\text { - Создание устойчивого спроса на иннова- } \\
\text { ционные фундаментальные и прикладные } \\
\text { разработки. } \\
\text { - Обеспечение благоприятной институцио- } \\
\text { нальной среды для внедрения инноваций }\end{array}$ & $\begin{array}{l}\text { Обеспечение высокого инновационного и техно- } \\
\text { логического уровня развития национальной эко- } \\
\text { номики }\end{array}$ \\
\hline НСБ & $\begin{array}{l}\text { Создание экономической базы для вы- } \\
\text { страивания системы выгодных для России } \\
\text { отношений с внешними акторами }\end{array}$ & $\begin{array}{l}\text { Создание условий для использования внешней } \\
\text { экономической базы в интересах народного хо- } \\
\text { зяйства России }\end{array}$ \\
\hline
\end{tabular}

Что касается структуры НЭБ, то, по нашему мнению, к ней можно отнести следующие виды безопасности:

1. Финансовая безопасность - защищённость финансовой системы и системы денежного обращения государства от негативных воздействий, способность фринансовой системы в полном объёме удовлетворять потребности национальной экономики в денежных ресурсах [16-20].

2. Производственная безопасность - способность национальной экономики полноценно выполнять свои функции по удовлетворению внутреннего и внешнего спроса [21] и обеспечивать высокие темпы экономического роста даже в ситуации угроз. Элементами производственной безопасности мы считаем продовольственную [22]-[25] и лекарственную [26], [27] безопасность.

3. Ресурсная безопасность - устойчивый доступ национальной экономики к природным ресурсам, необходимым для её стабильного функционирования (как за счёт стабильной системы внешнеторговых связей, так и благодаря развитию национальной сырьевой базы, а также на основе резервирования ресурсов [28], [29]).

4. Технологическая безопасность - наличие стабильного доступа к передовым технологиям, позволяющим обеспечить максимальную эффективность национальной экономики [30], [31].

5. Инфраструктурная безопасность - защищённость национальной инфраструктуры от негативных воздействий [32]-[35], инфрраструктурная обеспеченность национальной экономики (включая транспортную связность страны [36], [37]).

6. Демографическая безопасность - устойчивое воспроизводство человеческого капитала, повышение его качества [38].

7. Стоимостная безопасность - способность национальной экономики устойчиво производить и перераспределять большой объём добавленной стоимости, достаточный для удовлетворения потребностей государственного бюджета и обеспечения высокого качества жизни населения. Этот вид безопасности ранее не рассматривался в литературе, однако мы считаем необходимым его ввести. Задача национальной экономики - не только удовлетворять потребности населения, но и обеспечивать ему достойное качество жизни, чего можно добиться только в том случае, если в стране создаётся большой объём добавленной стоимости, который впоследствии распределяется между гражданами в виде трудовых доходов, доходов от капитала и социальных выплат. Аналогично, только большой объём добавленной стоимости позволит обеспечить полноценное финансирование государственных нужд за счёт налоговых отчислений. Таким образом, в рамках этого вида безопасности ставится задача максимизировать объём добавленной стоимости, создаваемой в стране (в том числе и за счёт роста производительности труда), обеспечить устойчивость производства этой добавленной стоимости и создать механизм её эфрфективного перераспределения (в частности, путём роста числа качественных рабочих мест с высокой оплатой труда). Отметим, что стоимостная безопасность в нашей стране пока не достигнута. Основным источником доходов в России является не добавленная стоимость, создаваемая в промышленности, а природная рента.

Очевидно, что однозначно разграничить эти элементы НЭБ невозможно - их соотношение также следует описывать балансовой таблицей, аналогичной Табл. 3.

Мы можем прийти к следующим выводам:

- национальная безопасность представляет собой комплекс частных видов безопасности, каждая из которых обеспечивает достижение какого-либо аспекта национальной безопасности. Однако разграничить эти частные виды безопасности затруднительно, поскольку они тесно связаны и влияют друг на друга. По этой причине целесообразно 
представлять национальную безопасность в виде балансовой таблицы, описывающей это взаимодействие и взаимное влияние частных видов национальной безопасности;

- место национальной экономической безопасности в системе НБ государства заключается в создании экономической основы для достижения НБ через обеспечение экономической базы для частных видов НБ. В свою очередь, частные виды НБ создают условия для достижения НЭБ страны;

- аналогичная ситуация имеет место и для НЭБ: в её состав также входят различные частные подвиды безопасности, которые создают условия для достижения целей друг друга, и тем самым позволяют достичь НЭБ;

- по нашему мнению, наряду с уже описанными в научной и прикладной литературе подвидами безопасности следует выделить такой новый элемент НЭБ, как стоимостную безопасность - способность национальной экономики устойчиво производить и перераспределять достаточный для достойной жизни населения и полноценного финансирования государственных потребностей объём добавленной стоимости. При отсутствии этого элемента НЭБ национальная экономика не сможет обеспечивать высокий темп экономического развития и справедливое распределение между всеми гражданами положительного эффректа экономического роста;

- мы считаем целесообразным расширение методологической базы обеспечения НБ России. Для этого, по нашему мнению, необходимо принять нормативно-правовые акты, которые бы давали определения и регламентировали цели и инструменты достижения ключевых видов и подвидов НБ (используя в том числе и опыт нормативного регулирования различных видов безопасности, накопленный в странах СНГ [39]). В свою очередь, в "Стратегии национальной безопасности Российской Федерации" следует разместить ссылки на эти перспективные нормативно-правовые акты. Аналогичные дополнения следует внести и в "Стратегию экономической безопасности Российской Федерации на период до 2030 года".

\section{Список использованных источников}

1. Белозёров И.П., Клоков Е.А. Место и значимость экономической безопасности в структуре национальной безопасности России // Вестник Омского университета. Серия: Экономика. - 2009. - № 2. - С. 94-100.

2. Косарев М.Н. Экономическая безопасность в системе национальной безопасности России // Вестник Уральского юридического института МВД России. - 2016. - № 1. C. 29-32.

3. Кузнецова Е.И. Национальная экономическая безопасность как предмет экономической стратегии государства // Национальные интересы: приоритеты и безопасность. - 2008. - T. 4. - № 7. - С. 30-34.

4. Титов А.Б., Михеенко О.В. Экономическая безопасность в системе национальной безопасности России // Общество: политика, экономика, право. - 2017. - № 1. - С. 4649.

5. Серебренников С.С., Моргунов Е.В., Мамаев С.М., Шерварли И.А. О стратегии экономической безопасности Российской Федерации на период до 2030 года // Вестник Томского государственного университета. Экономика. - 2018. - № 41. - С. 20-28.

6. Указ Президента Российской Федерации от 31.12.2015 г. № 683 "О Стратегии национальной безопасности Российской Федерации". Доступно онлайн по адресу: http://www.consultant.ru/cons/cgi/online.cgi?req=doc\&base $=$ LAW $\& n=191669 \& \mathrm{fld}=134 \& \mathrm{dst}=100$ 001,0\&rnd=0.9387890372287695\#010361500021716741. Проверено 02.12.2019.

7. Военная доктрина Российской Федерации. Утверждена Президентом РФ 25.12.2014 г. № Пр-2976. Доступно онлайн по адресу: http://www.consultant.ru/cons/cgi/online.cgi?rnd=E3D29D677B03AC0630AEE55D6EF994E2\& $\mathrm{r}$ eq $=$ doc $\&$ base $=$ LAW \& $n=172989 \& R E F F I E L D=134 \& R E F D S T=100076 \& R E F D O C=191669 \& R E F$ BASE=LAW\&stat=refcode\%3D16876\%3Bindex\%3D105\#1 rgzdwngyyr. Проверено 02.12.2019.

8. Указ Президента Российской Федерации от 13.05.2017 г. № 208 "О Стратегии экономической безопасности Российской Федерации на период до 2030 года". Доступно онлайн по адресу: http://kremlin.ru/acts/bank/41921. Проверено 17.10.2019.

9. Экономическая безопасность России: Общий курс / Под ред. В.К. Сенчагова. М.: Дело, 2005.

10.Илюткина Т.В. Сущностная и структурная характеристика понятия "экономическая безопасность" // Вестник Оренбургского государственного университета. - 2006. - № 8. - C. 10-15. 
11. Гостева С.Р. Экологическая безопасность Российской Федерации // Вестник Воронежского государственного аграрного университета. - 2006. - № 13. - С. 66-77.

12. Гусев А.А. Экономические и институциональные основы обеспечения экологической безопасности // Экономическая наука современной России. - 2019. - № 1. - С. 70-80.

13. Тимофеев Г.А., Орлинская О.М. Экологическая безопасность в системе национальной безопасности Российской Федерации // Власть. - 2017. - Т. 25. - № 2. - С. 6974.

14. Дмитриева Ю.В. Самосохранительное поведение как условие сокращения смертности и увеличения продолжительности жизни // Народонаселение. - 2019. - Т. 22. - № 3. - С. 93-101.

15. Котляров И.Д. Нестандартные формы занятости: позитивные, негативные, нейтральные // Вопросы регулирования экономики. - 2015. - Т. 6. - № 4. - С. 28-36.

16. Аганбегян А.Г., Ершов М.В. О связи денежно-кредитной и промышленной политики в деятельности банковской системы России // Деньги и кредит. - 2013. - № 6. - С. 3-11.

17. Барикаев Е.Н. Финансовая безопасность. - М.: ЮНИТИ-ДАНА, 2013. - 156 с.

18. Воробьёв Ю.Н., Воробьёва Е.И., Мощева А.С. Финансовая безопасность государства // Научный вестник: финансы, банки, инвестиции. - 2016. - № 2. - С. 14-17.

19. Петров И.В., Ермоленко О.М. Проблемы и перспективы банковского сектора в обеспечении экономической безопасности страны // Terra Economicus. - 2012. - Т. 10. № 1-3. - С. 142-146.

20. Ханин Г.И., Фомин Д.А. Инвестиционные, финансовые и институциональные предпосылки возрождения российской промышленности // Journal of Institutional Studies. 2019. - T. 11. - № 1. - С. 155-175.

21. Фёдорова Е.А., Николаев А.Э., Широкова Ю.С., Фёдоров Ф.Ю. Экспортная и импортная деятельность российских компаний в условиях санкций // Научноисследовательский финансовый институт. Финансовый журнал. - 2019. - № 3. - С. 75-90.

22. Голубятникова М.В., Бардулин Е.Н. Продовольственная безопасность как экономическая категория // Экономика и предпринимательство. - 2015. - № 4-1. - С. 154160.

23. Голубятникова М.В., Курбанов А.Х. Состояние и проблемы обеспечения продовольственной безопасности России в современных геополитических условиях // Региональные агросистемы: экономика и социология. - 2015. - № 1. - С. 6.

24. Плотников В.А., Сулейманова М.В. Анализ моделей обеспечения национальной продовольственной безопасности // Экономика сельскохозяйственных и перерабатывающих предприятий. - 2019. - № 5. - С. 7-12.

25. Сулейманова М.В., Курбанов А.Х. Место продовольственной безопасности в системе национальной безопасности государства в современных социальноэкономических условиях // В мире научных открытий. - 2015. - № 5. - С. 102-115.

26. Мельников С.В., Плотников В.А. Специфика ценообразования на российском фармацевтическом рынке в контексте обеспечения лекарственной безопасности // Экономическое возрождение России. - 2014. - № 2. - С. 127-132.

27. Фадеева Е.В. Доступность лекарственных препаратов в условиях медикаментозного эмбарго: по материалам исследований // Социологические исследования. - 2019. - № 4. - C. 77-85.

28. Козин М.Н., Сафиханов М.А. Проблемы функционирования Росрезерва в условиях санкций // Экономика, труд, управление в сельском хозяйстве. - 2018. - № 6. C. 8-14.

29. Уланов В.Л., Ковалёва А.И. О фрормировании стратегического резерва нефтти в России в целях обеспечения экономической безопасности и макроэкономической стабильности // Управленческие науки. - 2017. - Т. 7. - № 2. - С. 6-14.

30. Бабурина О.Н., Гуриева Л.К. Научно-технологический императив конкурентоспособности России в условиях концептуализации четвёртой промышленной революции (Industrie 4.0) // Национальные интересы: приоритеты и безопасность. - 2019. - Т. 15. - № 3. - C. 396-416.

31. Котляров И.Д. Аутсорсинговая модель организации российской нефртегазовой отрасли: проблемы и пути решения // Вопросы экономики. - 2015. - № 9. - С. 45-64.

32. Журавлёва Н.А. Концепция инфрраструктурной безопасности // Terra Economicus. -2009 . - T. 7. - № 4-2. - C. 133-134. 
33. Круглова И.А. Развитие энергетической инфраструктуры в аспекте стандартов "зелёной экономики" и обеспечения экономической безопасности // Учёные записки Международного банковского института. - 2018. - № 2. - С. 7-15.

34. Кузнецова Е.И. Национальная экономическая безопасность как предмет экономической стратегии государства // Национальные интересы: приоритеты и безопасность. - 2008. - Т. 4. - № 7. - С. 30-34.

35. План катастроф // Газета.ru, 10.07.2006. Доступно онлайн по адресу: https://www.gazeta.ru/comments/2006/07/10_е_695620.shtml. Проверено 02.12.2019.

36. Котляров И.Д. Геоэкономическое значение трансевразийского транспортного коридора // Записки Горного института. - 2009. - Т. 184. - С. 225-230.

37. Котляров И.Д. Интеграция в рыбной отрасли как инструмент обеспечения её развития // Вестник Тихоокеанского государственного экономического университета. 2013. - № 1. - С. 48-56.

38. Глушкова В.Г., Хорева О.Б. Демографическая безопасность России и её регионов: проблемы и пути их решения // Вестник Финансового университета. - 2014. - № 3. C. $14-25$.

39. Закон Республики Беларусь "О демографической безопасности Республики Беларусь" от 04.01.2002 № 80-3. Доступно онлайн по адресу: http://base.spinform.ru/show_doc.fwx?rgn=1832. Проверено 02.12.2019. 